\title{
AGRICULTURE AND ITS PLACE IN ECONOMIC DEVELOPMENT OF UZBEKISTAN
}

Dilorom Tadjibaeva, Tashkent Financial Institute, o_yuldashev@ hotmail.com

Based on the share of agriculture in GDP in Uzbekistan, the country can be allocated to a group of countries with a transitional type of economy that proceeds from agriculture to urbanization. At the same time specific local features exist. In Uzbekistan, about $65 \%$ of the population live in rural areas and currently about 3 million people are employed in agriculture. Although the trend shows a decline in the share of agriculture in gross domestic product, the number of people employed in agriculture has comparably slowly reduced. Agriculture's share of investment is only about $3-4 \%$ of the total amount of a fixed capital.

UDC Numbers: 332.1-3, DOI: 10.12955/cbup.2013.12

Key words: agriculture, growth, production, population, employment, elasticity, demand, supply, investment, dynamics, integration, cooperation, agro-industrial and financial groups

\section{Introduction}

There is no denial about the role and importance of agriculture as agriculture is the basis of human livelihood. The prosperity of society depends on its development. The particularity of agriculture makes it unique and it contributes to promoting economic development in the economy. Agriculture sector combined with other economic sectors can play a critical role in stimulating economic growth, reducing poverty, and ensuring environmental sustainability.

In Uzbekistan, since we gained independence, agrarian reforms have been held that have led to fundamental positive changes in agriculture. At the same time, however, there are some problems. Solution of these problems can help in creating favorable conditions for the further development of the economy.

\section{Analysis and evaluation of the main indicators of the agriculture development in Uzbekistan and its specific features}

The contribution of the agriculture sector in the development of the economy varies from country to country. It is one of the most important sectors of the economy. It is a hub of economic activities in agriculture base societies. It is a source of income and livelihood. It is a way of life. It is also a provider of environmental services. Moreover it is a source of food security.

Agriculture can be a source of growth for the national economy. Development of this sector through private investment can make this sector a main engine of growth of agriculture-related industries. Private investment in rural areas would be helpful in generating non-agriculture industries. In an 
agriculture-based economy of Uzbekistan, agriculture sector provides about $29 \%$ of the gross domestic product and is a source of employment for about $65 \%$ of the labor force in the economy.

Agriculture contributes to the development of countries in different ways. It depends on the attitude of the country towards agriculture as a source of economic growth and as a measure to reduce poverty. It is commonly known that countries in terms of agriculture development, agriculture contribution in GDP (gross domestic product) and employment, level of rural residents and poverty levels are divided into three categories (Developement of Agriculture, 2008):

- agriculture-based countries,

- developing from agriculture to urban economy countries,

- developed - urbanized countries.

These three groups of countries are very different from each other in the contribution of agriculture in the overall growth and the role of agriculture in economic development. In each of these countries, agriculture plays a specific role in growth and poverty reduction.

For agriculture-based countries agriculture is a major source of economic growth. It is providing an average of $32 \%$ of GDP growth. Over $70 \%$ of poor lower class of the population lives in the rural areas. In developing countries agriculture is not so far a major source of economic growth. However, most of the population including poor lower class is still concentrated in rural areas.

In urbanized, developed countries, the role of agriculture in economic growth is even smaller. Main dwellers including poor lower class are inhabitants of towns. The share of agro-food industry and related services accounts for one-third of the GDP.

From this point of view, our country can be included to the second group. At the same time it has some specific features. In our country, about $65 \%$ of the population lives in rural areas and currently about 3 million people are employed in agriculture. This represents a quarter of the total employment (Table 1).

Table 1: The dynamics of employment in Uzbekistan, in thousands

\begin{tabular}{|l|c|c|c|c|c|}
\hline & \multicolumn{5}{|c|}{ Years } \\
\cline { 2 - 7 } & 1990 & 1995 & 2000 & 2005 & 2010 \\
\hline The labor force & 9949 & 11074 & 12734 & 14858 & 16857 \\
\hline In percentage to base year & 100 & 111.3 & 128.0 & 149.3 & 169.4 \\
\hline The number of employed & 7941 & 8449 & 8983 & 10196 & 11642 \\
\hline In percentage to base year & 100 & 106.3 & 113.1 & 128.4 & 146.6 \\
\hline $\begin{array}{l}\text { The share of the total number of employed labor } \\
\text { force (in percentage) }\end{array}$ & 79.8 & 76.3 & 70.5 & 68.6 & 69.0 \\
\hline The number of people employed in agriculture & 3312 & 3121 & 3063.0 & 2996.5 & 2930.3 \\
\hline $\begin{array}{l}\text { The share of agriculture employment from general } \\
\text { employment in the economy, (in percentage) }\end{array}$ & 41.7 & 36.9 & 34.1 & 29.4 & 25.2 \\
\hline
\end{tabular}

Sources: Uzbekistan in figures (1991); Economic Survey for 1991-1996 (1996); Major trends of economic and social developement of Uzbekistan for years of independence (1990-2010) and forecast for 2011-2015 (2011). 
The main way of all countries to improve the manner of living and reducing poverty is to ensure sustainable growth. As a natural result of ongoing large-scale and fundamental reforms and changes, the growth rate of the economy, in recent years, has achieved a sustainable level. The average growth rate of the economy from 2000 to 2003 was $3-3.8 \%$ and at the start of the 2004 it was over $7 \%$. The GDP growth rate was at its highest at $9.5 \%$ in 2007 then it declined to $8.1 \%$ in 2010 .

In the meantime, it is worth to pay attention to the fact that economic growth is accompanied by some qualitative changes. The dynamics of the GDP growth demonstrates that in the structure of production and growth of the GDP, the share of industry and services has been increasing, and share of agriculture sector has shown decreasing trend over the years (Table 2).

Table 2: The share of industry, agriculture and services in GDP (in percentage)

\begin{tabular}{|l|l|r|r|r|r|r|r|r|}
\hline & \multicolumn{10}{|c|}{ Years } \\
\hline Indicators & 1990 & 2000 & 2005 & 2006 & 2007 & 2008 & 2009 & 2010 \\
\hline Industry & 17.6 & 13.8 & 20.7 & 22.1 & 24.0 & 22.3 & 24.0 & 24.0 \\
\hline Agriculture & 33.4 & 30.4 & 25.0 & 24.0 & 21.7 & 19.4 & 18.0 & 17.5 \\
\hline Service & 33.8 & 36.8 & 38.7 & 39.5 & 39.4 & 43.3 & 41.6 & 49.0 \\
\hline
\end{tabular}

Sources: Economy of Uzbekistan (2009); Major trends of economic and social developement of Uzbekistan for years of independence (1990-2010) and forecast for 2011-2015 (2011)

Agriculture sector, in 2000, provided $30.4 \%$ share to the GDP of the economy and it has been declining over the years. The share of agriculture to the GDP was $19.4 \%$ and $17.5 \%$ in 2008 and 2010, respectively. This is a natural process, but the capability of agriculture to contribute to economic growth is far from being exhausted.

Therefore, in Uzbekistan, one of the most important factors for recovery from crisis and in sustainable growth of the GDP has been the increase in the production of agricultural products. Agriculture sector helped in creating a strong resource base and establishing of modern processing enterprises in rural areas."We must be clear that it is not only new production and GDP growth but increase of food production, which always has a steady demand, and this demand for sure will grow in the future" (Karimov, 2009).

Despite the fact that the global financial and economic crisis circumspect socio-economic policies in the country but well-timed anti-crisis measures have provided a stable, balanced and sustainable economic growth in Uzbekistan. Though the circumstances of decreased demand and prices for a number of exported products was shock to the economy of Uzbekistan but the domestic demand for domestic products has been the key supporting factor of economy.

\section{Actual problems in agricultural development process and solutions}

Today, Uzbekistan's issue of food security is not a critical point of agenda. Climatic conditions allow us to gather crops even three times per season. Grain independence and everything that is connected with cultivation of cereals are in the realm of government interests and regulation. Calculations demonstrate that, firstly, per capita agriculture production increased $1.2 \%$ annually, but regarding the number of food product types, we are below physical consumption standards: mainly for production of 
meat and meat products, potatoes, and fruit. The supply of fruit and potatoes has increased about $63 \%$ and about $86 \%$, respectively.

There are problems with production of livestock products because of the fodder supply, in spite of the fact that livestock population have increased, the cultivation of feed crops are not growing. The data regarding the livestock is reported in Table 3. There is demand to increase production of these products for the domestic market and this is confirmed by the data. The demand for meat and meat products is satisfied only by $69.5 \%$.

Table 3: Dynamics of livestock and fodder crops

\begin{tabular}{|l|l|c|c|c|c|c|}
\hline & Measurement & \multicolumn{5}{|c|}{ Years } \\
\cline { 3 - 7 } & unit & 2000 & 2005 & 2008 & 2009 & 2010 \\
\hline Cattle & Thousands & 5281.8 & 6571.4 & 8024.8 & 8024.8 & 8510.8 \\
\hline Sheep and Goats & Thousands & 8863.6 & 11351.9 & 12559.4 & 13559.4 & 14438.3 \\
\hline Forage crops & Thousands & 429.0 & 290.3 & 284 & 324.6 & 320.4 \\
\hline \multicolumn{7}{|c|}{ The number of livestock per 1 hectare of forage crops } \\
\hline Cattle & Number & 12.3 & 22.6 & 28.3 & 24.7 & 29.6 \\
\hline Sheep and Goats & Number & 20.7 & 39.1 & 44.2 & 41.8 & 45.1 \\
\hline
\end{tabular}

Sources: Economy of Uzbekistan (2009); Agriculture of Uzbekistan (2011)

Secondly, there is a high capacity of production and export of fresh and processed fruits and vegetables. Up to 1991 our Republic produced on average 4.8-5.3 million tons fruits and 1.1-1.5 million tons were exported, and $1 / 4$ of the demand was formed by external factors. Current exports of these goods are twice lower. Only $5.5 \%$ of fruits, 3.3\% of vegetables, $9.8 \%$ of grapes, and $9.3 \%$ of melons and water-melons are exported.

We need return to lost international markets but it is difficult. Though it is the fact that our fruits and vegetables are "island of freedom" yet there are some domestic problems that our agriculture sector has been facing. A well-known fact is that an individual farmer and agriculture enterprise, with each new crop, faces a sales problem in both the domestic and international market. The productivity of the agriculture sector has been robust. The crop productivity, from 1991 to 2010, has increased by 2.1 times for grain, 2.4 times for potatoes, 1.3 times for vegetables, and 1.6 times for melons/watermelons. Productivity is good but the main income comes after sales. With each new crop there always arises the same main problem of lack of well-organized market both at domestic and international level. These problems start off with individuality and end in generality.

When the peculiarities of agriculture discussed, we mainly pay attention to climatic conditions. We still should not forget that agriculture has a "paradox of Samuelson", that ample harvest in the country leads to lower prices. The demand for agriculture products is price and income inelastic; as a result, producers receive less income or bear losses instead of expected high income. Such price instability in agriculture, of course, negatively affects the attractiveness of the industry. A feature of agriculture products is that not only their demand but also their supply is inelastic. The supply of land is perfectly inelastic and time has important role in the agriculture production. Not only the agriculture production but also the market period is related to natural biological factors (McConnell \& Brue, 1999). So we should be able to: a) properly determine the structure of sown areas, and b) to sell their 
harvest. It is necessary to switch to production based on desired demand estimated through market research. The production of agriculture products, without proper product placement and advertisement, would not be cost-effective. Another problem with the agriculture products is that, by the time the productions the final consumers, the value of these products increase by 2-3 times (Pronkina, 2008). This is the main margin earned by wholesalers and retailers whereas manufacturers of agricultural products complain about non-profitability.

Currently only about $1 / 4$ of the harvest is consumed in a row and about $3 / 4$ of the harvest is processed. The processing of the agriculture products let the processors to benefit from the agriculture production. The introduction of processing of agriculture output help introducing the diversification in the food industry. Most of the populations live in the rural areas. Backyards, for most of the families, are main source of income.

A private farm or a farm enterprise is the best option for the production in Uzbekistan. Integration and cooperation of the individual farm or a farm enterprise would strengthen their competitive advantage in the market. In the process of diversifying the food industry, producers and processors need to work on a common strategy to improve the competitiveness of production. During this process the main objective should be the reduction in cost of production. There are also some major issues the processing of raw material. There is a competition in the processing industry. This competition in the processing industry increases the quality and product range of final consumer goods of the processing industry. These relationships in production chain increase investment in the processing industry. These industries not only are focused on creating of profit but also help to achieve social benefits such as creation of employment opportunities. The goals for the development of partnership and integration of structures can be obtained by addressing these issues. Many domestic manufacturers, in Uzbekistan, are doing this. These manufactures already have established their vertically integrated structures.

The major incentive for any business is the good return. The food industry is also characterized with the desire to earn good returns. The volume of investment into the formation of productive capital, in Uzbekistan, has increased in recent decades. The share of investment in the GDP was $19.4 \%$ in 2002. It was $21.1 \%$ in 2007 and it stood at $25 \%$ of the GDP in 2010. In 2002 the funds attracted from foreign public investment programs totaled 448 million U.S. dollars. The attracted foreign investment and loans were 1018 million and 2824.5 million in 2007 and 2010, respectively. But merely 3-4\% of the investment was directed to agriculture sector (see Table 4).

It will certainly affect the course of modernization in agriculture. The capital formation of agriculture, in 2010 , was aimed at 530.6 billion. There were five major source of funding in agriculture sector: $32.9 \%$ government budget funds, $27.7 \%$ private funds, $19.5 \%$ bank loans and $7.1 \%$ foreign investments and loans, $11 \%$ special melioration fund.

Speaking about profitability, it should be noted that the level is achieved mainly due to low payroll in the industry. It is commonly known that there is a close relationship between investment, productivity and wages. If the industry or region has excessive manpower, but poorly paid, from the macroeconomic position, it is unprofitable to invest here. It is advantageous to obtain the same result by using cheap labor, and the funds are used in the industries where the higher the return is indispensable. It results in a competition for investments between sectors. In this aspect rural industry has been in a disadvantage.

Wages in the agricultural sector account for $50-60 \%$ of the level in the industry, promising a reduction in investment in the industry. Innovation and modernization in agriculture requires a serious approach 
of both science and research. Financial funding and a strong government support are needed for the modernization of the agriculture sector. In our republic, currently, only $0.6 \%$ of the state budget is allocated for the development of science and research. Only a small part of these funds go to areas related to agriculture.

Table 4: Investment to fixed asset formation by industry

\begin{tabular}{|l|c|c|c|c|c|c|c|c|}
\hline & \multicolumn{9}{|c|}{ Years } \\
\cline { 2 - 10 } & 1990 & 1995 & 2000 & 2005 & 2007 & 2008 & 2009 & 2010 \\
\hline Total & 100 & 100 & 100 & 100 & 100 & 100 & 100 & 100 \\
\hline Industrial purpose & 58.3 & 68.1 & 57.5 & 57.5 & 70.1 & 75.4 & 75.7 & 73.5 \\
\hline Industry & 16.8 & 45.1 & 29.7 & 32.6 & 36.8 & 32.4 & 28.4 & 26.1 \\
\hline Agriculture & 26.7 & 8.4 & 5.7 & 8.2 & 3.3 & 3.1 & 3.1 & 3.5 \\
\hline Construction & & 0.5 & 0.5 & 0.3 & 1.2 & 2.3 & 2.8 & 2.5 \\
\hline $\begin{array}{l}\text { Transport and } \\
\text { Communications }\end{array}$ & 5.4 & 7.5 & 16.7 & 13.0 & 22.8 & 26.3 & 31.4 & 29.9 \\
\hline $\begin{array}{l}\text { Trade and public } \\
\text { catering }\end{array}$ & & 5.7 & 4.3 & 3.1 & 1.7 & 2.5 & 2.5 & \\
\hline Others & 9.4 & 0.9 & 0.6 & 0.3 & 0.7 & 0.4 & 7.5 & 11.5 \\
\hline Non-production & 41.7 & 31.9 & 42.5 & 42.5 & 29.9 & 24.6 & 24.3 & 26.5 \\
\hline
\end{tabular}

Sources: Economy of Uzbekistan (2009); Major trends of economic and social developement of Uzbekistan for years of independence (1990-2010) and forecast for 2011-2015 (2011)

For the development of the processing industry, it needs proper infrastructure: energy supply, water, sewage, etc. Building the infrastructure certainly provides a part of the employment of the rural population. On the other hand, it requires a lot of funds. So the establishment of agro-industrialfinancial groups, the creation of farmers and farmers' cooperatives of various sales and processing would help to solve many problems.

\section{Conclusion}

At the present, our country became independent on food security and sustainable economic growth. But, nevertheless, based on the characteristics of the agricultural sector and the market economy sale of manufactured product are of primary importance.

Therefore, there should be given a special meaning: 1) to determine the crop pattern, and 2) to recover lost foreign markets, carrying out marketing research and producing of the environmentally friendly products.

The study shows that while agriculture entities itself are not engaged in the sale of manufactured products to end users, the mediators are the main benefit takers. Therefore, it is necessary to attract investment to accelerate the development of modern enterprises in deep processing of agricultural production and trade networks, and paying more attention to research and development.

For this purpose, it is necessary to observe historical and international experience. Dekhans and farmers who have opportunities to process themselves need cooperation in creating different cooperatives, agro-industrial and financial groups. 


\section{References}

Center for Economic Research. (2009). Economika Uzbekistana [Economy of Uzbekistan]. In Statisticheskiy sbornik [Economic survey data book]. (p. 45-75). Tashkent, Uzbekistan: CER.

Karimov, I. A. (2009). Mirovoy finansovo-economicheskiy crisis, puti i mery po ego preodoleniyu v usloviyakh Uzbekistana [World Financial and Economic Crisis, ways and measures to overcome its consequences in Uzbekistan]. (p. 38 - 39). Tashkent: Uzbekistan.

McConnell, K. R. \& Brue, S. L. (1999). Economics [Economics] (13rd ed.). (p. 444-445, 636-640, 725-730). Moscow, Russia: INFRA-M.

Pronkina, T. (2008). Na osnove sprosa [On the basis of demand]. Economicheskoe obozrenie [Economic Review], 2, 17. Tashkent, Uzbekistan: CER.

The State Committee of the Republic of Uzbekistan on statistics. (2011). Selskoe khozyaystvo Uzbekistana [Agriculture of Uzbekistan]. In Ezhegodniy staticheskiy sbornik [Statistical Yearbook] (p. 19-25, 30-31, 143-170). Tashkent, Uzbekistan: UzStat.

The State Committee of the Republic of Uzbekistan on statistics. (1991). Uzbekistan v tsifrakh.Kratkiy Statisticheskiy sbornik [Uzbekistan in figures. Short Statistical Book]. (p. 27-36). Tashkent, Uzbekistan: UzStat.

The World Bank. (2007). Agriculture for Development. World Development Report 2008 (p. 10-105). Washington, D.C.: The World Bank. Retrieved March 20, 2013. http://dx.doi.org/10.1596/978-08213-6807-7

Uzbekistan National News Agency. (1996). Economicheskiy Obzor za 1991-1996 [Economic Survey for 1991-1996]. In Uzbekistan za gody nezavisimosti [Uzbekistan for years of independence]. (p. 7475). Tashkent, Uzbekistan: UzA.

Uzbekistan National News Agency. (2011). Osnovnie tendentsii economicheskogo razvitiya Uzbekistana za gody nezavisimosti (1990-2010) I prognoz na 2011-2015 [Major trends of economic and social development of Uzbekistan for years of independence (1990-2010) and forecast for 20112015]. In Ezhegodniy statisticheskiy sbornik [Statistical Yearbook]. (p. 96-99). Tashkent, Uzbekistan: UzA. 